\title{
Motivasi melakukan fraud dan faktor-faktor yang mempengaruhinya
}

\author{
Prapti Antarwiyati ${ }^{1}$, Raras Ega Purnomo ${ }^{2}$ \\ ${ }^{1,2}$ Program Studi Akuntansi, Universitas Islam Indonesia, Yogyakarta, Indonesia \\ e-mail: ${ }^{1}$ prapti.antarwiyati@uii.ac.id
}

\section{A R T I K E L I N F O}

Article history:

Available online

Keywords:

motivation to perform fraud, organizational justice, internal control, compensation suitability, information asymmetry

\section{A B S T R A C T}

This research aims to analyze the factors that motivate a person to perform fraud. These factors include, organizational justice, internal control, compliance compensation, and information asymmetry. The research data obtained from the results of questionnaires collection of 52 respondents who are employees of Bank Perkreditan Rakyat Bank Bantul, Yogyakarta Special Region. Hypothesis testing in this research using multipleregression model with SPSS software. The results of this research indicate that organizational justice and internal control significantly negatively affect the motivation to perform fraud. Compliance suitability does not affect the motivation to perform fraud. Information asymmetry has a significant positive effect on the motivation to perform fraud. Company leaders or equals are expected to continue to maintain and maintain justice organization that has been formed in the company. The company is also expected to always enforce an effective internal control system and continue to evaluate the internal control system that has been operating in the company. In addition, the provision of information should be balanced in accordance with the needs so that no use of excessive information that can motivate someone to commit fraud.

\begin{abstract}
A B S T R A K
Penelitian ini bertujuan untuk menganalisis faktor-faktor yang memotivasi seseorang untuk melakukan tindak kecurangan (fraud). Faktor-faktor tersebut meliputi, keadilan organisasi, pengendalian internal, kesesuaian kompensasi, dan asimetri informasi. Data penelitian diperoleh dari hasil pengumpulan kuesioner sebanyak 52 responden yang merupakan karyawan Bank Perkreditan Rakyat Bank Bantul, Daerah Istimewa Yogyakarta. Pengujian hipotesis dalam penelitian ini menggunakan model regresi berganda (multiregression) dengan software SPSS. Hasil penelitian ini menunjukkan bahwa keadilan organisasi dan pengendalian internal berpengaruh negatif signifikan terhadap motivasi melakukan fraud. Kesesuaian kompensasi tidak berpengaruh terhadap motivasi melakukan fraud. Asimetri informasi berpengaruh positif signifikan terhadap motivasi melakukan fraud. Pimpinan perusahaan atau yang sederajat diharapkan dapat terus menjaga dan mempertahankan keadilan organisasi yang sudah terbentuk di perusahaan. Perusahaan juga diharapkan untuk selalu menegakkan sistem pengendalian internal yang efektif dan terus melakukan evaluasi terhadap sistem pengendalian internal yang sudah berjalan di perusahaan. Selain itu, pemberian informasi harus dilakukan seimbang sesuai dengan kebutuhan sehingga tidak terjadi pemanfaatan informasi yang berlebih yang dapat memotivasi seseorang untuk melakukan kecurangan.
\end{abstract}

\section{Pendahuluan}

Pada mulanya tugas pokok Bank Pengkreditan Rakyat (BPR) diarahkan untuk menunjang pertumbuhan dan modernisasi ekonomi perdesaan. Dengan semakin berkembangnya kebutuhan masyarakat, tugas BPR tidak hanya ditujukan bagi masyarakat pedesaan, tetapi juga mencakup pemberian jasa perbankan bagi masyarakat golongan ekonomi lemah di daerah perkotaan (Wijaya dan Suswandari 2014). Berdasarkan Undang-Undang Nomor 10 Tahun 1998 Tentang Perubahan Atas UU No. 7 Tahun 1992 Tentang Perbankan, Bank Perkreditan Rakyat berperan dalam menghimpun dana dari masyarakat kemudian menyalurkannya dalam bentuk kredit, menyediakan pembiayaan bagi nasabah dengan prinsip bagi hasil, dan menempatkan dananya dalam bentuk Sertifikat Bank Indonesia (SBI), deposito berjangka, sertifikat deposito, dan/atau tabungan pada bank lain. 
Berdasarkan data statistik perbankan pada Bank Indonesia, jumlah BPR yang tersebar di seluruh Indonesia hingga awal tahun 2016 adalah sebesar 1.642 (Bank Indonesia 2016). Hal ini membuktikan bahwa perkembangan BPR yang cukup baik dengan tersebarnya bank tersebut pada berbagai wilayah di Indonesia. Namun belakangkan ini, kasus-kasus kecurangan sedang marak diperbincangkan di Indonesia.Tindak kecurangan dibuktikan dengan adanya likuidasi beberapa bank, diajukannya manajemen BUMN dan swasta ke pengadilan, kasus kejahatan perbankan, manipulasi pajak, korupsi pada komisi penyelenggaraan pemilu, dan DPRD (Herman 2013). Banyaknya likuidasi bank termasuk didalamnya BPR, ditutup operasionalnya, dan dicabut izinnya mengindikasikan bahwa tindak kecurangan pada sector perbankan marak terjadi. Sebuah data yang dipaparkan oleh Lembaga Penjamin Simpanan (LPS) menyebutkan bahwa likuidasi BPR di Indonesia sejak 19 Januari 2016 hingga 21 Januari 2016 mencapai 66 kasus yang terdiri dari 44 kasus selesai likuidasi dan 22 kasus yang masih dalam proses likuidasi (Lembaga Penjamin Simpanan 2016).

Lembaga Penjamin Simpanan (LPS) mencatat bahwa kebanyakan perbankan yang pailit bahkan sampai dilikuidasi disebabkan oleh kecurangan dan penggelapan yang dilakukan pengurus atau pemilik bank (Fauzan 2014). Selain itu, sebagian besar terjadinya likuidasi bank disebabkan karena kecurangan dan konflik di antara manajemen bank yang bersangkutan (Wicaksono 2014).

Beberapa penelitian terdahulu telah membahas mengenai masalah tindak kecurangan (fraud). Penelitianpenelitian sejenis dilakukan antara lain oleh Aranta (2013), Delfi et al. (2014), Puspitadewi dan Irwandi (2012), Puspasari dan Suwardi (2012), Yendrawati dan Paramitha (2014), dan Hamdani dan Albar (2016). Penelitian yang dilakukan oleh Delfi et al. (2014) memperoleh hasil bahwa efektifitas pengendalian internal dan kesesuaian kompensasi berpengaruh signifikan terhadap kecenderungan kecurangan akuntansi. Selanjutnya, Aranta (2013) memperoleh hasil bahwa moralitas aparat dan asimetri informasi berpengaruh signifikan terhadap kecenderungan akuntansi. Disisi lain, Yendrawati dan Paramitha (2014) menemukan bukti bahwa motivasi melakukan kecurangan didorong oleh keadilan organisasi dan didukung oleh kualitas pengendalian internal. Kelemahan pada pengendalian internal telah diidentifikasi dapat mengakibatkan terjadinya fraud (Hamdani dan Albar 2016).

Berdasarkan penelitian yang telah dilakukan sebelumnya, penelitian ini akan mereplikasi dan mengembangkan penelitian yang telah dilakukan khususnya pada penelitian Yendrawati dan Paramitha (2014). Penulis akan melakukan penelitian untuk mengetahui faktor-faktor yang berpengaruh terhadap motivasi seseorang dalam melakukan kecurangan (fraud). Faktor-faktor tersebut meliputi keadilan organisasi, pengendalian internal, kesesuaian kompensasi, dan asimetri informasi.

\section{Tinjauan Pustaka dan Perumusan Hipotesis}

\section{Fraud}

Menurut Tuanakotta (2013) fraud adalah perbuatan yang disengaja oleh satu atau lebih anggota manajemen, atau pengelola, atau karyawan, atau pihak ketiga, melalui penipuan untuk memperoleh keuntungan yang tidak sah atau melawan hukum. Menurut ACFE yang dipaparkan Tuanakotta (2013) membagi fraud (kecurangan) menjadi tiga jenis berdasarkan perbuatan, yaitu; (1) penyalahgunaan asset (asset misappropriation) merupakan penyalahgunaan/pencurian aset atau harta perusahaan merupakan bentuk fraud yng paling mudah dideteksi krena sifatnya yang tangible atau dapat diukur/dihitung, (2) pernyataan palsu atau salah pernyataan (fraudulent statement), meliputi tindakan yang dilakukan oleh pejabat atau eksekutif suatu perusahaan atau instansi pemerintah untuk menutupi kondisi keuangan yang sebenarnya dengan melakukan rekayasa keuangan dalam penyajian laporan keuangannya untuk memperoleh keuntungan, dan (3) korupsi, merupakan jenis fraud yang paling sulit dideteksi karena menyangkut kerjasama dengan pihak lain dimana hal ini merupakan jenis terbanyak di negara-negara berkembang yang memiliki penegak hokum yang lemah dan kurangnya kesadaran akan tata kelola yang baik. Di Indonesia, korupsi atau fraud tidak hanya terjadi di sektor lembaga pemerintah saja, melainkan di sektor lembaga swasta juga banyak terjadi (Hamdani et al. 2017).

\section{Fraud Triangle}

Cressey (1953) mengembangkan sebuah teori yang dikenal sebagai fraud triangle, yaitu bahwa terdapat tiga kondisi yang selalu hadir saat terjadi kecurangan laporan keuangan. Ketiga kondisi tersebut dijelaskan sebagai berikut:

\section{Tekanan (pressure)}

Manajemen atau pegawai lain merasakan dorongan atau tekanan untuk melakukan kecurangan (Arens et al. 2012). Tekanan dapat muncul dalam bentuk kesulitan keuangan atau dalam beberapa kasus berasal dari keserakahan. Simbol dari keserakahan misalnya gaya hidup mewah yang dapat dikenali dari perbandingan antara aset pribadi seseorang dengan potensi pendapatan miliknya (Sriyana, Yogi, dan Syamsudin 2014). 
Menurut Yesiariani dan Rahayu (2017), tekanan dari luar (external pressure) terbukti berpengaruh positif signifikan terhadap fraud pada laporan keuangan.

2. Kesempatan (opportunity)

Situasi yang membuka kesempatan bagi manajemen atau pegawai untuk melakukan kecurangan (Arens et al. 2012). Menurut Albrecht et al. (2012), sedikitnya ada enam faktor utama yang dapat meningkatkan kesempatan yang dimiliki seseorang untuk melakukan fraud yaitu pengendalian internal yang lemah, ketidakmampuan dalam menilai kualitas kerja, tidak adanya sanksi yng tegas, kurangnya akses terhadap informasi, pengabaian dan sikap apatis, dan kurangnya upaya untuk melakukan jejak audit.

3. Rasionalisasi (rationalization)

Terdapat sikap, karakter, atau serangkaian nilai-nilai etis yang membolehkan manajemen atau pegawai untuk melakukan tindakan yang tidak jujur, atau mereka berada dalam lingkungan yang cukup menekan yang membuat mereka merasionalisasi tindakan yang tidak jujur (Arens et al. 2012). Rasionalisasi juga terbukti berpengaruh positif terhadap terjadinya fraud pada laporan keuangan (Yesiariani dan Rahayu 2017).

\section{Keadilan Organisasi}

Folger dan Cropanzano (1998) menjelaskan bahwa keadilan organisasi meliputi persepsi anggota organisasi tentang kondisi keadilan yang mereka alami atau rasakan dalam organisasi tersebut, secara khusus tentang rasa keadilan yang terkait dengan alokasi penghargaan organisasi seperti gaji dan promosi. Ketika keadilan organisasi dirasa buruk, maka akan mengakibatkan ketidakpuasan, kebencian, dan kemarahan melawan organisassi yang mana hal semacam inilah yang mendorong seseorang untuk berbuat menyimpang dan melakukan tindak kecurangan (Yendrawati dan Paramitha 2014). Namun apabila keadilan dalam suatu perusahaan dirasa baik, maka karyawan akan merasa puas dan tidak terdapat niatan untuk melakukan tindak kecurangan. Penyataan tersebut didukung dengan hasil penelitian Yendrawati dan Paramitha (2014), Puspitadewi dan Irwandi (2012), dan Herman (2013) yang menunjukkan bahwa keadilan organisasi berpengaruh negatif terhadap motivasi melakukan kecurangan. Berdasarkan pertimbangan di atas, maka dirumuskan hipotesis sebagai berikut:

$\mathrm{H}_{1}$ : Keadilan organisasi berpengaruh negatif terhadap motivasi melakukan fraud.

\section{Sistem pengendalian Internal}

Berdasarkan PSA No. 69 tentang Pertimbangan atas Pengendalian Intern dalam Audit Laporan Keuangan, pengendalian internal adalah suatu proses yang dijalankan oleh dewan komisaris manajemen, dan personel lain entitas yang didesain untuk memberikan keyakinan memadai tentang pencapaian tiga golongan tujuan berikut ini: keandalan pelaporan keuangan, efektivitas dan efisiensi operasi, dan kepatuhan terhadap hukum dan peraturan yang berlaku (Ikatan Akuntan Indonesia, n.d.). Pengendalian internal yang efektif dapat melindungi dari pencurian, penggelapan, penyalahgunaan aktiva pada lokasi yang tidak tepat serta memberikan jaminan yang wajar terhadap informasi bisnis yang akurat demi keberhasilan perusahaan (Delfi et al. 2014). Apabila disuatu perusahaan sudah memiliki pengendalian yang efektif, maka pengendalian internal tersebut dapat digunakan untuk meminimalisir tindak kecurangan yang hendak dilakukan oleh karyawan pada perusahaan tersebut. Sebaliknya, jika pengendalian internal yang lemah telah diidentifikasi dapat mengakibatkan terjadinya fraud (Hamdani dan Albar 2016).

Penyataan tersebut didukung dengan hasil penelitian Yendrawati dan Paramitha (2014), Delfi et al. (2014), dan Puspitadewi dan Irwandi (2012) yang menunjukkan bahwa pengendalian internal berpengaruh negatif terhadap motivasi melakukan kecurangan. Berdasarkan pertimbangan di atas, maka dirumuskan hipotesis sebagai berikut:

$\mathrm{H}_{2}$ : Pengendalian internal berpengaruh negatif terhadap motivasi melakukan fraud.

\section{Kesesuaian Kompensasi}

Kompensasi adalah keseluruhan balas jasa yang diterima oleh pegawai sebagai akibat dari pelaksanaan pekerjaan di organisasi dalam bentuk uang atau lainnya (Hariandja 2007). Pemberian kompensasi yang sesuai dengan kinerja karyawan akan membuat karyawan tersebut merasa puas dan dihargai dengan jerih payah yang sudah mereka berikan. Kepuasan tersebut yang nantinya membuat karyawan enggan untuk melakukan tindak kecurangan. Penyataan tersebut didukung dengan hasil penelitian Delfi et al. (2014) yang menunjukkan bahwa kesesuaian kompensasi berpengaruh negatif terhadap motivasi melakukan kecurangan. Namun, dalam penelitian Faisal (2013) dan Wilopo (2006) menunjukkan hasil bahwa kesesuaian kompensasi tidak berpengaruh terhadap tindak kecurangan. Oleh karena itu, penelitian ini akan menguji kembali mengenai pengaruh hubungan antara kesesuaian kompensasi dengan motivasi melakukan fraud sehingga dirumuskan hipotesis sebagai berikut: 
$\mathrm{H}_{3}$ : Kesesuaian kompensasi berpengaruh negatif terhadap motivasi melakukan fraud.

\section{Asimetri Informasi}

Asimetri informasi adalah situasi dimana terjadi ketidakselarasan informasi antara pihak yang memiliki atau menyediakan informasi dengan pihak yang membutuhkan informasi (Schott 2003). Organisasi yang memiliki asimetri informasi yag tinggi antara pihak pengelola dengan pihak yang membutuhkan dapat menimbulkan motivasi untuk melakukan kecurangan yang semakin tinggi. Oleh sebab itu, pemberian informasi harus dilakukan sesuai dengan yang dibutuhkan sehingga tidak terjadi pemanfaatan informasi yang berlebih yang dapat memotivasi seseorang untuk melakukan kecurangan yang berakibat merugikan pihak perusahaan dan luar perusahaan. Penyataan tersebut didukung dengan hasil penelitian Aranta (2013) yang menunjukkan bahwa asimetri informasi berpengaruh positif terhadap motivasi melakukan kecurangan. Berdasarkan pertimbangan di atas, maka dirumuskan hipotesis sebagai berikut:

$\mathrm{H}_{4}$ : Asimetri informasi berpengaruh positif terhadap motivasi melakukan fraud.

Hipotesis-hipotesis yang akan diuji digambarkan dalam model seperti di Gambar 1.

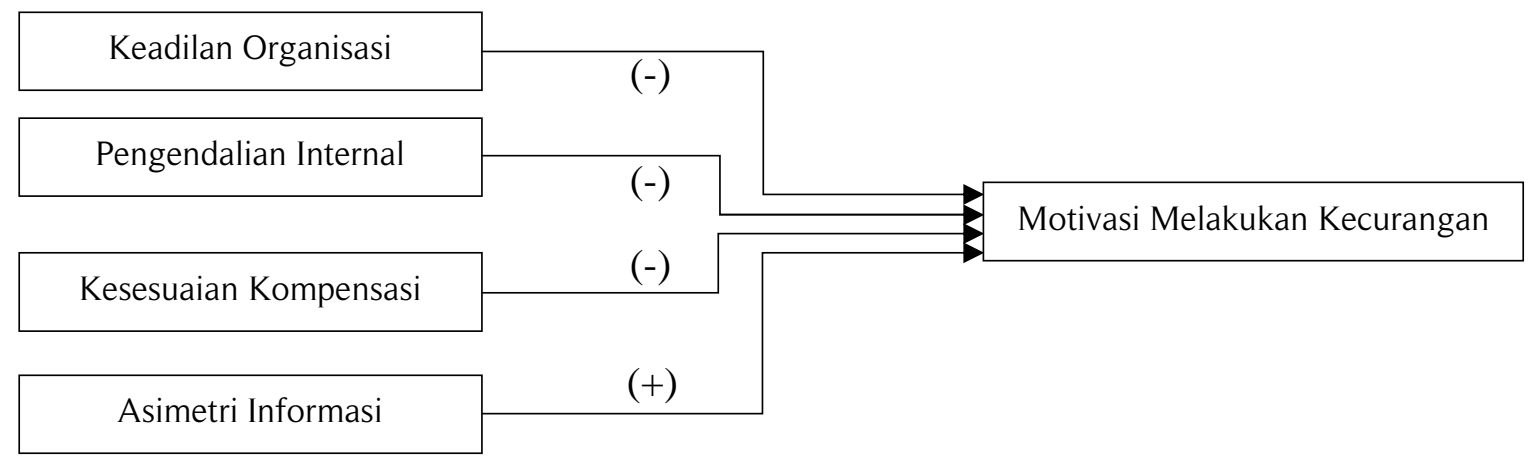

Gambar 1. Hubungan Antar Variabel

\section{Metoda Penelitian}

\section{Populasi dan Sampel Penelitian}

Populasi yang akan digunakan dalam penelitian ini adalah karyawan yang berada pada Bank Perkreditan Rakyat yang ada di wilayah Daerah Istimewa Yogyakarta yang terdaftar pada Perhimpunan Bank Perkreditan Rakyat (PERBARINDO). Sampel yang digunakan yaitu karyawan yang bekerja pada Bank Perkreditan Rakyat Bank Bantul di Daerah Istimewa Yogyakarta.

Sumber data yang digunakan dalam penelitian ini adalah data primer, yaitu data yang diperoleh secara langsung dari responden. Metode pengumpulan data yang dilakukan dalam penelitian ini adalah dengan menggunakan metode angket/kuesioner. Teknik pengambilan sampel pada penelitian ini adalah dengan menggunakan metode convenience sampling dikarenakan tidak terdapat kriteria responden yang cukup berarti.

\section{Variabel Penelitian dan Pengukuran}

Variabel yang digunakan dalam penelitian ini terdiri dari 5 (lima) variabel yaitu motivasi melakukan fraud, keadilan organisasi, pengendalian internal, kesesuaian kompensasi, dan asimetri informasi. Pengukuran data dari masing-masing jawaban responden menggunakan skala 1-6. Skala tersebut terdiri dari Sangat Tidak Setuju (STS), Tidak Setuju (TS), Kurang Setuju (KS), Cukup Setuju (CS), Setuju (S), dan Sangat Setuju (SS).

\section{Variabel Motivasi Melakukan Fraud}

Motivasi adalah kumpulan perilaku yang memberikan landasan bagi seseorang untuk bertindak dalam suatu cara yang diarahkan kepada tujuan spesifik tertentu(Samsuni 2017). Motivasi seseorang melakukan fraud dijelaskan dalam salah satu teori yang disebut dengan fraud triangle theory. Faktor yang mempengaruhi motivasi melakukan fraud adalah tekanan (pressure), kesempatan (opportunity), dan rasionalisasi (rationalization). Pengukuran variabel motivasi melakukan kecurangan (fraud) menggunakan kombinasi kuesioner hasil pengembangan Mustikasari (2013) dan Simanjuntak (2013) dengan 6 item pertanyaan (lihat Tabel 1). 
Tabel 1. Pertanyaan Kuesioner Variabel Motivasi Melakukan Fraud

\begin{tabular}{clc}
\hline No & \multicolumn{1}{c}{ Pertanyaaan } & Penelitian Terdahulu \\
\hline 1. & Tidak wajar jikabiaya dicatat lebih tinggi. & \\
2. & Karyawan mengetahui dan menaati peraturan di perusahaan. & \\
3. & Menjadi masalah bila transaksi memiliki bukti pendukung ganda. & Mustikasari (2013) dan \\
4. & Tidak wajar jikaterdapat pengeluaran tanpa bukti pendukung. & Simanjuntak (2013) \\
5. & Tidak wajar jika harga beli peralatandicatat lebih tinggi. & \\
6. & Adanya aturan tegas terhadap pihak yang melakukan kecurangan. & \\
\hline
\end{tabular}

\section{Variabel Keadilan Organisasi}

Folger dan Cropanzano (1998) menjelaskan keadilan organisasi meliputi persepsi anggota organisasi mengenai kondisi keadilan yang mereka alami dalam organisasi tersebut, secara khusus tentang rasa keadilan yang terkait dengan alokasi penghargaan organisasi seperti haji dan promosi. Pengukuran variabel keadilan organisasi menggunakan kuesioner hasil pengembangan Yendrawati dan Paramitha (2014) dengan 5 item pertanyaan. Pengukuran data dari masing-masing jawaban responden menggunakan skala 1-6.

Tabel 2. Pertanyaan Kuesioner Variabel Keadilan Organisasi

\begin{tabular}{clc}
\hline No & \multicolumn{1}{c}{ Pertanyaaan } & Penelitian Terdahulu \\
\hline 1. & Semua kepentingan karyawan telah dipertimbangkan pimpinan sebelum & \\
2. & Pimpinan mengumant keputusan. & \\
3. & Pimpinan memberikan informasi saat saya meminta keterangan. & Yendrawati dan Paramitha \\
4. & Keputusan yang diambil dilaksanakan kepada semua karyawan. & \\
5. & Semua keputusan dibuat untuk kepentingan perusahaan. & \\
\hline
\end{tabular}

\section{Variabel Pengendalilan Internal}

Pengendalian internaldijelaskan pada PSA No. 69 tentang Pertimbangan atas Pengendalian Intern dalam Audit Laporan Keuangan sebagai suatu proses yang dijalankan oleh dewan komisaris manajemen, dan personel lain entitas yang didesain untuk memberikan keyakinan memadai tentang pencapaian tiga golongan tujuan berikut ini: keandalan pelaporan keuangan, efektivitas dan efisiensi operasi, dan kepatuhan terhadap hukum dan peraturan yang berlaku (Ikatan Akuntan Indonesia, n.d.). Pengukuran variabel pengendalian internal menggunakan kombinasi kuesioner hasil pengembangan Yendrawati dan Paramitha (2014) dan Herman (2013) dengan 10 item pertanyaan.

Tabel 3. Pertanyaan Kuesioner Variabel Pengendalian Internal

\begin{tabular}{clc}
\hline No & \multicolumn{1}{c}{ Pertanyaaan } & Penelitian Sebelumnya \\
\hline 1. & Perusahaan memiliki struktur organisasional yang jelas. & \\
2. & Karyawan diberikan deskripsi pekerjaan, pelatihan pegawai, rencana & \\
3. & Transaksional, jadwansaksi dan angang terjadi telah diotoritas dengan baik. & \\
4. & Proses penjagaan aset perusahaan telah memadai. & Yendrawati dan Paramitha \\
5. & Pemeriksaan kekayaan perusahaan dilakukan saat diperlukan. & (2014) dan Herman \\
6. & Pemeriksaan internal seluruh transaksi dilakukan secara independen. & $(2013)$ \\
7. & Informasi kegiatan operasional dijamin kelengkapannya. & \\
8. & Aman dan jelas otoritasnya dalam mengakses file terkait kegiatan & \\
9. & Dalam perusahaan ini, pengawasan dilakukan secara rutin. \\
10. & Pengawas memverifikasi setiap tugas yang diberikan kepada karyawan. & \\
\hline
\end{tabular}

\section{Variabel Kesesuaian Kompensasi}

Kompensasi adalah keseluruhan balas jasa yang diterima oleh pegawai sebagai akibat dari pelaksanaan pekerjaan di organisasi dalam bentuk uang atau lainnya yang dapat berupa gaji, upah, bonus, insentif, dan tunjangan lainnya seperti tunjangan kesehatan, hari raya, uang makan, uang cuti, dan lain-lain (Hariandja 2007). 
Pengukuran variabel kesesuaian kompensasi menggunakan kuesioner hasil pengembangan Wilopo (2006) dengan 6 item pertanyaan.

Tabel 4. Pertanyaan Kuesioner Variabel Kesesuaian Kompensasi

\begin{tabular}{clc}
\hline No & \multicolumn{1}{c}{ Pertanyaaan } & Penelitian Terdahulu \\
\hline 1. & Kompensasi keuangan diukur sesuai dengan prestasi pekerjaan. & \\
2. & Karyawan menguasai tugas pekerjaannya. & \\
3. & $\begin{array}{l}\text { Promosi diberikan atas dasar prestasi kerja karyawan. } \\
\text { 4. }\end{array}$ & $\begin{array}{l}\text { Perusahaan ini dikelola oleh manajemen sedemikian sehingga karyawan } \\
\text { memulai dan menyelesaikan pekerjaan dengan baik. }\end{array}$ \\
5. $\begin{array}{l}\text { Penanggung jawab penyusunan laporan keuangan merupakan tugas } \\
\text { menantang yang harus diciptakan dalam waktu tertentu. }\end{array}$ & Wilopo (2006) \\
6. $\begin{array}{l}\text { Penanggung jawab penyusunan laporan keuangan dapat memaksimalkan } \\
\text { kemampuan dan pengetahuan di bidangnya. }\end{array}$ & \\
\hline
\end{tabular}

Variabel

Tabel 7. Hasil Uji Validitas

\begin{tabular}{|c|c|c|c|c|}
\hline Variabel & Item & $r$ hitung & $\mathrm{r}$ table & Keterangan \\
\hline \multirow[t]{5}{*}{ Keadilan Organisasi } & $\mathrm{X} 1.1$ & 0,893 & 0,2787 & Valid \\
\hline & X1.2 & 0,887 & 0,2787 & Valid \\
\hline & $\mathrm{X} 1.3$ & 0,913 & 0,2787 & Valid \\
\hline & X1.4 & 0,940 & 0,2787 & Valid \\
\hline & X1.5 & 0,939 & 0,2787 & Valid \\
\hline \multirow[t]{10}{*}{ Pengendalian Internal } & X2.1 & 0,616 & 0,2787 & Valid \\
\hline & $\mathrm{X} 2.2$ & 0,789 & 0,2787 & Valid \\
\hline & X2.3 & 0,819 & 0,2787 & Valid \\
\hline & $X 2.4$ & 0,857 & 0,2787 & Valid \\
\hline & $X 2.5$ & 0,821 & 0,2787 & Valid \\
\hline & X2.6 & 0,865 & 0,2787 & Valid \\
\hline & X2.7 & 0,793 & 0,2787 & Valid \\
\hline & $\mathrm{X} 2.8$ & 0,874 & 0,2787 & Valid \\
\hline & X2.9 & 0,848 & 0,2787 & Valid \\
\hline & $\mathrm{X} 2.10$ & 0,759 & 0,2787 & Valid \\
\hline \multirow{6}{*}{ Kesesuaian Kompensasi } & X3.1 & 0,876 & 0,2787 & Valid \\
\hline & X3.2 & 0,887 & 0,2787 & Valid \\
\hline & X3.3 & 0,918 & 0,2787 & Valid \\
\hline & X3.4 & 0,941 & 0,2787 & Valid \\
\hline & X3.5 & 0,915 & 0,2787 & Valid \\
\hline & X3.6 & 0,784 & 0,2787 & Valid \\
\hline \multirow[t]{4}{*}{ Asimteri Informasi } & X4.1 & 0,642 & 0,2787 & Valid \\
\hline & $X 4.2$ & 0,901 & 0,2787 & Valid \\
\hline & $\mathrm{X} 4.3$ & 0,898 & 0,2787 & Valid \\
\hline & $X 4.4$ & 0,725 & 0,2787 & Valid \\
\hline \multirow[t]{6}{*}{ Motivasi Melakukan Fraud } & X5.1 & 0,685 & 0,2787 & Valid \\
\hline & X5.2 & 0,805 & 0,2787 & Valid \\
\hline & X5.3 & 0,934 & 0,2787 & Valid \\
\hline & X5.4 & 0,933 & 0,2787 & Valid \\
\hline & $\times 5.5$ & 0,823 & 0,2787 & Valid \\
\hline & X5.6 & 0,556 & 0,2787 & Valid \\
\hline
\end{tabular}

Sumber: data primer, diolah 2016

Berdasarkan Tabel 7, semua butir pertanyaan dari setiap variabel keadilan organisasi, pengendalian internal, kesesuaian kompensasi, asimetri informasi, dan motivasi melakukan kecurangan adalah valid karena nilai $r$ hitung lebih besar dari $r$ tabel.

\section{Hasil Uji Reliabilitas}

Uji reliabilitas dimaksudkan untuk mengetaui tingkat konsistensi terhadap instrument-instrumen yang diukur. Pada penelitian ini, pengukuran dilakukan dengan menggunakan alat uji cronbach alpha. Suatu konstruk 
dinyatakan reliabel apabila nilai cronbach alpha $\geq 0,60$ (Ghozali dan Latan 2015). Hasil uji reliabilitas ditunjukkan pada Tabel 8.

Tabel 8. Hasil Uji Reliabilitas

\begin{tabular}{lccc}
\hline \multicolumn{1}{c}{ Variabel } & Cronbach Alpha & Nilai Kritis & Keterangan \\
\hline Keadilan Organisasi & 0,828 & 0,60 & Reliabel \\
Pengendalian Internal & 0,783 & 0,60 & Reliabel \\
Kesesuaian Kompensasi & 0,813 & 0,60 & Reliabel \\
Asimetri Informasi & 0,813 & 0,60 & Reliabel \\
Motivasi Melakukan Fraud & 0,804 & 0,60 & Reliabel \\
\hline
\end{tabular}

Sumber: data primer, diolah 2016

Tabel 8 menunjukkan bahwa seluruh variabel penelitian memiliki nilai cronbach alpha lebih dari 0,60. Dengan demikian, dapat disimpulkan bahwa semua variabel penelitian memiliki reliabilitas yang baik.

\section{Hasil Analisis Regresi dan Pengujian Hipotesis}

Berdasarkan hasil uji menggunakan SPSS, nilai adjusted $R^{2}$ diperoleh sebesar 0,513 . Hal ini berarti variabel keadilan organisasi, pengendalian internal, kesesuaian kompensasi, dan asimetri informasi dapat menjelaskan variabel motivasi melakukan fraud sebesar 51,3\%. Sedangkan sisanya sebesar $48,7 \%$ dijelaskan oleh variabel lain yang tidak diteliti dalam penelitian ini.

Tabel 10. Hasil Uji Hipotesis

\begin{tabular}{lccc}
\hline \multicolumn{1}{c}{ Variabel } & Prediksi Hubungan & Koefesien & P-value \\
\hline Konstan & & & \\
Keadilan Organisasi & - & 41,129 & 0,000 \\
Pengendalian Internal & - & $-0,400$ & 0,005 \\
Kesesuaian Kompensasi & - & $-0,211$ & 0,004 \\
Asimetri Informasi & + & $-0,186$ & 0,096 \\
Adjusted R-Squared & 0,513 & 0,733 & 0,000 \\
\hline
\end{tabular}

\section{Keadilan Organisasi Berpengaruh Negatif terhadap Motivasi Melakukan Fraud}

Hasil pengujian dari hipotesis pertama memiliki nilai signifikansi sebesar $0,005<0,05$ sehingga variabel keadilan organisasi memiliki pengaruh signifikan terhadap motivasi melakukan fraud. Nilai koefisien yang negatif sebesar 0,400 menunjukkan bahwa variabel keadilan organisasi mempunyai hubungan yang tidak searah dengan motivasi melakukan fraud. Berdasarkan hasil tersebut, keadilan organisasi berpengaruh negatif signifikan terhadap motivasi melakukan fraud. Dengan demikian dapat disimpulkan bahwa hipotesis pertama diterima. Hal ini dikarenakanapabila di suatu perusahaan tercipta keadilan organisasi dengan baik, misalnya pada Bank Perkreditan Rakyat Bank Bantul semua keputusan perusahaan dilaksanakan secara konsisten kepada semua karyawan yang terlibat didalamnya, maka semua karyawan tersebut akan merasa diperlakukan secara adil sesuai dengan porsi masing-masing. Rasa keadilan organisasi sangatlah penting karena jika di dalam suatu organisasi terdapat pihak yang merasa diperlakukan tidak adil, maka hal ini akan dapat memunculkan rasa ketidakpuasan pada organisasi tersebut sehingga akan menciptakan motivasi di dalam diri karyawan untuk melakukan tindakan kecurangan.

Hasil penelitian ini didukung oleh penelitian Yendrawati dan Paramitha (2014), Puspitadewi dan Irwandi (2012), dan Herman (2013) yang menyatakan bahwa keadilan organisasi berpengaruh negatif signifikan terhadap motivasi melakukan kecurangan. Hal ini sesuai dengan hasil pengamatan peneliti bahwa keadilan organisasi yang baik di suatu organisasi memiliki peran penting dalam menurunkan tingkat motivasi melakukan fraud.

\section{Pengendalian Internal Berpengaruh Negatif terhadap Motivasi Melakukan Fraud}

Hasil pengujian dari hipotesis kedua memiliki nilai signifikansi sebesar 0,004 $<0,05$ sehingga variabel pengendalian internal memiliki pengaruh signifikan terhadap motivasi melakukan fraud. Nilai koefisien yang negatif sebesar -0,211 menunjukkan bahwa variabel pengendalian internal mempunyai hubungan yang tidak 
searah dengan motivasi melakukan fraud. Berdasarkan hasil tersebut, pengendalian internal berpengaruh negatif terhadap motivasi melakukan fraud. Dengan demikian dapat disimpulkan bahwa hipotesis kedua diterima.

Teori fraud triangle menjelaskan bahwa terdapat tiga kondisi yang menyebabkan terjadinya kecurangan yaitu tekanan, kesempatan, dan rasionalisasi. Salah satu kesempatan yang dapat menyebabkan karyawan melakukan fraud yaitu karena lemahnya pengendalian internal pada perusahaan. Apabila di suatu perusahaan memiliki pengendalian internal yang lemah, maka akan membuka kesempatan bagi karyawan perusahaan untuk melakukan fraud. Sebaliknya apabila perusahaan sudah memiliki pengendalian yang efektif, maka pengendalian internal tersebut dapat digunakan untuk meminimalisir tindak kecurangan yang hendak dilakukan oleh karyawan pada perusahaan tersebut. Pada Bank Perkreditan Rakyat Bank Bantul dimungkinkan telah memiliki pengendalian internal yang baik sehingga dapat meminimalisir motivasi karyawan untuk melakukan fraud.

Hasil penelitian ini didukung oleh penelitian Yendrawati dan Paramitha (2014), Delfi et al. (2014), dan Puspitadewi dan Irwandi (2012) yang menyatakan bahwa pengendalian internal berpengaruh negatif terhadap motivasi melakukan kecurangan. Hal ini sesuai dengan hasil pengamatan peneliti bahwa pengendalian internal yang baik di suatu perusahaan memiliki peran penting dalam menurunkan tingkat motivasi melakukan fraud.

\section{Kesesuaian Kompensasi Berpengaruh Negatif terhadap Motivasi Melakukan Fraud}

Hasil pengujian dari hipotesis ketiga memiliki nilai signifikansi sebesar 0,096>0,05 sehingga variabel kesesuaian kompensasi tidak memiliki pengaruh terhadap motivasi melakukan fraud. Nilai koefisien yang negatif sebesar 0,186 menunjukkan bahwa variabel kesesuaian kompensasi mempunyai hubungan yang tidak searah dengan motivasi melakukan fraud. Berdasarkan hasil tersebut, kesesuaian kompensasi tidak berpengaruh terhadap motivasi melakukan fraud. Dengan demikian dapat disimpulkan bahwa hipotesis ketiga ditolak.

Menurut Bologna (1993), penyebab fraud dapat dijelaskan dengan GONE Theory yang salah satu faktor yang mendorong seseorang melakukan fraud adalah greed atau keserakahan. Hal ini berkaitan dengan adanya perilaku serakah yang secara potensial ada di dalam diri setiap orang. Kesesuaian kompensasi bukan merupakan faktor yang mempengaruhi seseorang untuk melakukan fraud dimungkinkan karena tujuan utama karyawan Bank Perkreditan Rakyat Bank Bantul adalah melayani masyarakat dan mungkin saja sifat keserakahan tidak terdapat pada diri karyawan Bank BPR tersebut.

Dengan demikian, hasil pengujian hipotesis ketiga ditolak karena tidak didukung oleh data. Hal ini menunjukkan bahwa hipotesis nol gagal ditolak atau dengan kata lain kesesuaian kompensasi tidak berpengaruh terhadap motivasi untuk melakukan fraud. Hal penelitian ini didukung oleh penelitian Faisal (2013) dan Wilopo (2006) yang menunjukkan hasil bahwa kesesuaian kompensasi tidak berpengaruh terhadap tindak kecurangan.

\section{Asimetri Informasi Berpengaruh Positif terhadap Motivasi Melakukan Fraud}

Hasil pengujian dari hipotesis keempat memiliki nilai signifikansi sebesar $0,000<0,05$ sehingga variabel asimetri informasi memiliki pengaruh signifikan terhadap motivasi melakukan fraud. Nilai koefisien yang positif sebesar 0,733 menunjukkan bahwa variabel asimetri informasi mempunyai hubungan yang searah dengan motivasi melakukan fraudsehingga dapat disimpulkan bahwa hipotesis keempat diterima. Hal ini dimungkinkan karena berdasarkan hasil jawaban responden karyawan pada Bank Perkreditan Rakyat Bank Bantul, menunjukkan bahwa hanya pihak internal perusahaan yang memahami dan mengetahui seluruh informasi yang berkaitan dengan pembuatan laporan keuangan. Dengan demikian dapat disimpulkan bahwa Bank Perkreditan Rakyat Bank Bantul telah memiliki keselarasan informasi yang baik antara pihak yang menyediakan informasi dengan pihak yang membutuhkan informasi tersebut sehingga karyawan tidak termotivasi untuk melakukan fraud.

Hasil penelitian ini didukung oleh penelitian Aranta (2013) yang menyatakan bahwa asimetri informasi berpengaruh positif signifikan terhadap motivasi melakukan kecurangan. Hal ini sesuai dengan hasil pengamatan peneliti bahwa asimetri informasi yang tinggi di suatu perusahaan memiliki peran dalam meningkatkan motivasi melakukan fraud.

\section{Simpulan}

Penelitian ini bertujuan untuk mengetahui faktor-faktor yang memotivasi seseorang untuk melakukan tindak kecurangan (fraud). Penelitian ini dilaksanakan akibat banyaknya kasus kecurangan di Indonesia yang sedang banyak diperbincangkan, dibuktikan dengan adanya likuidasi beberapa bank termasuk di dalamnya BPR (Herman 2013). Sebagian besar perbankan yang pailit bahkan sampai dilikuidasi disebabkan oleh kecurangan dan penggelapan yang dilakukan pengurus atau pemilik bank (Fauzan 2014). Berdasarkan analisis data yang telah dilakukan pada, maka dapat disimpulkan bahwa variabel keadilan organisasi dan pengendalian internal berpengaruh negatif signifikan terhadap motivasi melakukan fraud. Variabel kesesuaian kompensasi tidak berpengaruh terhadap 
motivasi melakukan fraud. Selain itu, variabel asimetri informasi berpengaruh positif signifikan terhadap motivasi melakukan fraud.

Implikasi penelitian ini, pimpinan perusahaan atau yang sederajat diharapkan dapat terus menjaga dan mempertahankan keadilan organisasi yang sudah terbentuk di perusahaan. Perusahaan juga diharapkan untuk selalu menegakkan sistem pengendalian internal yang efektif dan terus melakukan evaluasi terhadap sistem pengendalian internal yang sudah berjalan di perusahaan. Selain itu, pemberian informasi harus dilakukan seimbang sesuai dengan kebutuhan sehingga tidak terjadi pemanfaatan informasi yang berlebih yang dapat memotivasi seseorang untuk melakukan kecurangan. Faktor yang tidak terbukti berpengaruh seperti kesesuaian kompensasi juga dapat dipertimbangkan oleh pimpinan perusahaan untuk meminimalisir kemungkinan terjadinya fraud.

Penelitian ini memiliki beberapa keterbatasan yang mungkin dapat mempengaruhi hasil penelitian yang ingin dicapai, antara lain; data yang digunakan dalam penelitian ini dihasilkan dari instrumen melalui persepsi jawaban responden sehingga dimungkinkan tidak menggambarkan situasi yang sebenarnya. Sampel penelitian hanya terbatas pada Bank Pengkreditan Rakyat (BPR) Bank Bantul, Daerah Istimewa Yogyakarta. Penelitian selanjutnya diharapkan untuk dapat menambahkan beberapa variabel, seperti penegakan peraturan dan komitmen organisasi.

\section{Daftar Referensi}

Albrecht, W. S., C. O. Albrecht, C. C. Albrecht, dan M. F. Zimbelman. 2012. Fraud Examination. South-Western: Cengage Learning.

Aranta, P. Z. 2013. Pengaruh moralitas aparat dan asimetri informasi terhadap kecenderungan kecurangan akuntansi (studi empiris pemerintah kota Sawahlunto. Jurnal Akuntansi 1 (1): 160. https://doi.org/10.1017/CBO9781107415324.004.

Arens, A. A., R. J. Elder, dan M. S. Beasley. (2012). Auditing and assurance services: an integrated approach (14th ed.). Boston: Prentice Hall.

Bank Indonesia. 2016. Statistik perbankan. Diakses dari https://www.bi.go.id/id/statistik/perbankan/bprkonvensional/kelembagaan/Default.aspx.

Bologna, J. 1993. Handbook of corporate fraud: prevention, detection, and investigation. Boston: ButterworthHeinemann.

Cressey, D. R. 1953. Others people money, a study in the social psychology of embezzlement. Montclair: Patterson Smith.

Delfi, T., R. Anugerah, dan A. A. A. 2014. Pengaruh efektifitas pengendalian internal dan kesesuaian kompensasi terhadap kecenderungan kecurangan akuntansi (survey pada perusahaan BUMN cabang Pekanbaru). JOM FEKON 1 (2): 1-17.

Faisal, M. 2013. Analisis fraud di sektor pemerintahan kabupaten Kudus. Accounting Analysis Journal 2 (1): 6773. https://doi.org/ISSN 2252-6765.

Fauzan. 2014. LPS: 90\% bank dilikuidasi akibat kecurangan pemilik. Koran SINDO, 2014. Diakses dari https://daerah.sindonews.com/read/937888/151/lps-90-bank-dilikuidasi-akibat-kecurangan-pemilik1418701642.

Folger, R., dan R. Cropanzano. 1998. Organizational justice and human resource management. Thousand Oaks, California: SAGE Publications, Inc.

Ghozali, I. 2005. Aplikasi analisis multivariate dengan program SPSS. Semarang: Badan Penerbit Universitas Diponegoro.

Ghozali, I., dan H. Latan. 2015. Partial least squares konsep, teknik dan aplikasi menggunakan program smartPLS 3.0. Edisi kedua. Semarang: Badan Penerbit Universitas Diponegoro.

Hamdani, R., dan A. R. Albar. 2016. Internal controls in fraud prevention effort: a case study of an Islamic finance bank. Jurnal Akuntansi dan Auditing Indonesia 20 (2): 127-135.

Hamdani, R., Kumalahadi, dan D. Urumsah. 2017. The classification of corruption in indonesia: a behavioral perspective. SHS Web of Conferences 10002. 
Hariandja, M. T. E. 2007. Manajemen sumber daya manusia: pengadaan, pengembangan, pengkompensasian, dan peningkatan produktivitas pegawai. Jakarta: Gramedia Widiasarana Indonesia.

Herman, L. A. 2013. Pengaruh keadilan organisasi dan sistem pengendalian intern terhadap kecurangan (studi empiris pada kantor cabang utama bank pemerintah di kota Padang). 1-21. https://doi.org/10.1017/CBO9781107415324.004.

Ikatan Akuntan Indonesia. n.d. PSA no. 69 tentang pertimbangan atas pengendalian intern dalam audit laporan keuangan.

Lembaga Penjamin Simpanan. 2016. Bank yang dilikuidasi. 2016. Diakses dari http://www.lps.go.id/bank-yangdilikuidasi.

Mustikasari, D. P. 2013. Persepsi pegawai dinas se-kabupaten Batang tentang faktor-faktor yang mempengaruhi kecurangan (fraud). Semarang, Universitas Negeri Semarang.

Nurgiyantoro, B., Gunawan, dan Marzuki. 2004. Statistik terapan: untuk penelitian ilmu-ilmu sosial. Yogyakarta: Gadjah Mada University Press.

Pemerintah Republik Indonesia. 1998. Undang-undang nomor 10 tahun 1998 tentang perubahan atas UU no. 7 tahun 1992 tentang perbankan.

Puspasari, N., dan E. Suwardi. 2012. Pengaruh moralitas individu dan pengendalian internal terhadap kecenderungan kecurangan akuntansi: studi eksperimen pada konteks pemerintahan daerah. Simposium Nasional Akuntansi XV, Banjarmasin, 20-23 September 2012. Diakses dari http://sna.akuntansi.unikal.ac.id/makalah/102-SIPE-38.pdf.

Puspitadewi, P., dan S. A. Irwandi. 2012. Hubungan keadilan organisasional dan kecurangan pegawai dengan moderating kualitas pengendalian internal. The Indonesian Accounting Journal 2 (2): 159-172. https://doi.org/10.14414/tiar.v2i02.93.

Samsuni. 2017. Manajemen sumber daya manusia. Jurnal IImiah Keislaman dan Kemasyarakatan 17 (1): 113-124.

Schott, W. R. 2003. Financial accounting theory. 3rd edition. Toronto: Prentice Hall.

Simanjuntak, N. S. T. 2013. Pengaruh keefektifan pengendalian intern bidang akuntansi dan pengembangan mutu karyawan terhadap pencegahan kecurangan akuntansi di perusahaan. Universitas Sumatera Utara.

Sriyana, J., H. Yogi, dan M. Syamsudin. 2014. The budget misallocation mechanism in Indonesia's bureaucracy. International Journal of Business and Management Study 1 (2): 26-30.

Tuanakotta, T. M. 2013. Audit berbasis IS A (international standards on auditing). Jakarta: Salemba Empat.

Wicaksono, A. 2014. Banyak BPR dilikuidasi karena curang? Kompas.com, 2014. Diakses dari https://ekonomi.kompas.com/read/2014/05/16/0717201/Banyak.BPR.Dilikuidasi.karena.Curang.

Wijaya, A. L., dan Y. Suswandari. 2014. Analisis perbedaan tingkat likuiditas BPR konvensional dan BPR syariah guna mengetahui tingkat kesehatan keuangan bank perkreditan rakyat (studi pada bpr di kabupaten Magetan dan Ponorogo). Jurnal LPPM 2 (2): 55-62.

Wilopo. 2006. Analisis faktor-faktor yang berpengaruh terhadap kecenderungan kecurangan akuntansi: studi pada perusahaan publik dan badan usaha milik negara di Indonesia. Simposium Nasional Akuntansi 9 Padang, 21-26 Agustus 2006.

Yendrawati, R., dan K. A. Paramitha. 2014. Pengaruh keadilan organisasi terhadap motivasi melakukan kecurangan dengan kualitas pengendalian internal sebagai variabel moderating. Inovasi dan Kewirausahaan 3 (1): 49-59.

Yesiriani, M. dan I. Rahayu. 2017. Deteksi financial statement fraud: Pengujian dengan fraud diamond. Jurnal Akuntansi dan Auditing Indonesia 2 (1): 49-60. 